\title{
Effect of Corm Size and Varieties on Corm/Cormels Production and Vase Life of Gladiolus
}

\author{
K. R. Joshi ${ }^{1}$, D. M. Gautam ${ }^{2}$, D. R. Baral ${ }^{2}$ and U. K. Pun ${ }^{3}$ \\ ${ }^{1}$ District Agriculture Development Office (DADO), Dadeldhura, ${ }^{2}$ Institute of Agriculture and \\ Animal Sciences, Rampur, Chitwan, ${ }^{3}$ Himalayan Flora, Kathmandu \\ e-mail: joshi_khem@yahoo.com
}

\begin{abstract}
An experiment was conducted to assess the effect of corm size and varieties on corm/cormels production and vase life of gladiolus ( Gladious grandiflorus L.) under Chitwan condition. A Field experiment was conducted in a farmer's field at Gunjanagar VDC, Chanauli, Chitawan during November 2008 to April 2009. The experiment consisted of 12 treatment combinations laid out in two factorial Randomized complete block design (RCBD) with three replications. Four sizes of corms viz. $2-3 \mathrm{~cm}, 3-4 \mathrm{~cm}, 4-5 \mathrm{~cm}$ and 5-6 cm and three varieties viz. American Beauty, Interpret and Yellow Summer Sunshine formed 12 treatment combinations. Laboratory experiment was conducted to determine the effect of corm size and varieties on the vase life of harvested cut spikes of gladiolus at ambient temperature at the central laboratory of the Institute of Agriculture and Animal Sciences (IAAS), Rampur, Chitwan, Nepal. Corm size and varieties significantly affected corm/cormels production and vase life of gladiolus. Large sized corms $(5-6 \mathrm{~cm})$ performed better with respect to number of daughter corms and cormels per plant. Similarly, large sized corms $(5-6 \mathrm{~cm})$ showed better performance with respect to postharvest behavior such as total number of florets opened/spike (11.40), days to first and 100\% floret withering as compared to small sized $(2-3 \mathrm{~cm})$ corms. Significant variation among three varieties was observed in most of the characters. Numbers of daughter corms were found highest in Yellow Summer Sunshine while maximum numbers of cormels/plant were found in Interpret. Similarly, Interpret proved best having more number of florets opened per spike and more days needed to first and $100 \%$ floret withering.
\end{abstract}

Key words: gladiolus, spike, corm/cormels, withering

\section{Introduction}

Gladiolus (Gladiolus grandiflorus L.) belonging to Iridaceae family, is a glamorous flower, a flower of perfection also known as "Queen of bulbous flowers", has been rated as one of the most popular flowers in the world (Makhijani 1973), occupying $4^{\text {th }}$ position after rose, chrysanthemum and carnation in international cut flower trade (Bose \& Yadav 1989) with its magnificient inflorescence grown in herbaceous borders, bed rockery, pot and also for cut flowers. It is the first commercially grown cut flower crop in Nepal since 1988 and ranks number one in terms of production and consumption in Nepal (Pun 2004) occupying about 200 ha of land under its cultivation. The demand of gladiolus spikes is 350045000 daily in Kathmandu and around 800000 spikes are produced annually (Gauchan et al. 2009). It is the largest grown cut flower in Nepal which occupies the top position with $70 \%$ of all sales (Devtech 1995).

Large numbers of cultivars are developed every year, and hundreds of cultivars degenerated every year (Deshraj \& Misra 1998). Characterization of these 
cultivars and identification of suitable ones, both for cut flower and corm/cormels production assumes significance for improving productivity and returns to the farmers. Chitwan district having 3.5 times more bulb output than hills of Kalimpong (India) has emerged as one of the most important districts for growing gladiolus (FAN 2007). But suitability of varieties for corm/cormels production is still not known. It is imperative therefore to investigate the potentiality of various gladiolus varieties for corm/cormels production so that an alternate enterprise along with cut flower can be established in Chitwan.

Quantity as well as quality of flower spikes and vase life of spikes depends upon various factors, out of which size of mother corms play important role (Sharma \& Gupta 2003). Size of planting material is important for obtaining good vegetative growth, quality spikes and corm production. Although the work regarding influence of corm size on one variety are available but a thorough and comprehensive work taking different grades and multiple varieties is not yet available in our context. In consideration of the above facts, the present study was undertaken to investigate the effect of corm size and varieties on corm/cormels production and vase life of gladiolus under Chitwan conditions.

\section{Methodology}

A field experiment was conducted during November 2008 to April 2009 in the commercial gladiolus farmers' field in Gunjanagar VDC, Chanauli, Chitwan. The experiment was laid out in a factorial RCBD with 12 treatments and 3 replications. Four size of corms (2-3 $\mathrm{cm}, 3-4 \mathrm{~cm}, 4-5 \mathrm{~cm}$ and 5-6 cm) and three commercial varieties (American Beauty, Interpret, and Yellow Summer Sunshine) were used as two different factors. American Beauty is the most famous variety among the gladiolus farmers because of its pink colored flowrets. Interpret is a dwarf variety as compared to other two varieties having red colored florets and more numbers of cormels/plant. Likewise, Yellow Summer Sunshine is tall variety having yellow colored florets and largest number and size of daughter corm and cormels. The total experimental area was $196.65 \mathrm{~m} 2$ $(17.1 \mathrm{~m} \times 11.5 \mathrm{~m})$ with an individual plot size of $2.1 \mathrm{~m} \mathrm{x}$ $1 \mathrm{~m}$ i.e. $2.1 \mathrm{~m} 2$ where four sized corms were planted in the furrows at the crop geometry of $(30 \times 25) \mathrm{cm}^{2}$. Well decomposed farmyard manure (FYM) was applied @ of $20 \mathrm{t} / \mathrm{ha}$, 2 weeks before planting. Half dose of nitrogen, full doses of phosphorous and potash were incorporated into the soil at the time of corm planting. Standard cultural operations were followed for successful production of gladiolus cut flowers. First irrigation was followed by side dressing with $1 / 4 \mathrm{~N}$ and earthing up at 45 DAP. Second irrigation was followed by side dressing with remaining nitrogen and earthing up at 75 DAP. Periodic removal of multiple sprouts from the plot was followed after completion of emergence assuming that retained single sprout gives the standard sized spikes. Periodic weeding was done in the experimental plot to reduce the weed population. The soil samples from the experimental site were taken and analyzed at soil science lab of Agriculture Research Station, Pakhribas, Dhankuta, Nepal. Soil reaction was found slightly acidic (6.14) and texture was found silty loam while nitrogen $(0.19 \%)$ and phosphoros (74 kg/ha) were found medium and potash (264 kg/ha) was found high. Organic matter was found low (1.69\%). Daily maximum-minimum temperature and relative humidity were recorded during the post harvest experiment using thermo hygrometer. The average maximum temperature was $29.5^{\circ} \mathrm{C}$ on 23rd March while average minimum temperature was $17^{\circ} \mathrm{C}$ on 5 th and 8th March. Relative humidity was the highest (64.67\%) on 18th February while it was lowest (41.83\%) on 11th March.

Observations on number and weight of daughter corms and numbers of cormels/plant and were recorded. Laboratory experiment was conducted to determine the effect of corm size and varieties on the vase life of harvested cut spikes of gladiolus at ambient temperature of central laboratory of Institute of Agriculture and Animal Sciences (IAAS), Rampur, Chitwan, Nepal during 15th February, 2009 to 23rd March, 2009. Harvested spikes of three varieties of gladiolus planted each with four corm size for field experiment were used as experimental materials and experiment was laid out in a factorial completely randomized design (CRD) having corm size as factor A and varieties as factor $\mathrm{B}$. Thus altogether 12 treatment combinations were formed. In each treatment 5 spikes were taken for the study as replication. Each set up was replicated twice to confirm the trend of post harvest behaviour. Analysis of variance for all parameters was done using statistical analysis through MSTAT-C programme. All the analyzed data were subjected to DMRT for mean separation at 5\% level of significance. 


\section{K. R. Joshi et al./Effect of Corm Size ........}

\section{Results and Discussion Number of daughter corms}

Highly significant variation was recorded for number of daughter corms among the different sized corms planted (Table 2). It ranged from 1.33 to 1.84. Large sized $(5-6 \mathrm{~cm})$ corms yielded the maximum number of daughter corms (1.87) which was statistically at par with daughter corms produced by $4-5 \mathrm{~cm}$ sized corms (1.75) while lowest numbers of daughter corms (1.33) were produced by smallest $(2-3 \mathrm{~cm})$ corms. Number of daughter corms of the tested varieties was found highly significant (Table 2). Yellow Summer Sunshine yielded the maximum number of daughter corms (2.27) followed by Interpret (1.41) while lowest numbers of daughter corms were recorded in American Beauty (1.25). A wide range of variation in this parameter might be due to genetic constitution of the varieties. The result obtained by Arora and Khanna (1985), Hegde and Patil (1995) and Sindhu and Verma (1995) for varietal performance were in conformity of present findings.

\section{Weight of daughter corms}

Highly significant variation was recorded on weight of daughter corms among the different sizes of corms planted (Table 2). The weight of daughter corms ranged from $43.44 \mathrm{~g}$ to $74.70 \mathrm{~g}$. Bigger size of mother corms produced daughter corms with higher weight and vice versa. Significantly higher weight (74.70 g) of daughter corms was observed in plants from 5-6 cm corm whereas lower weight (43.44 g) of daughter corms was observed in plants from 2-3 cm corm. Large size of daughter corms from larger mother corms might be the reason for higher weight of daughter corms. An increase in weight of daughter corms with large mother corms was reported by Bankar and Mukhopadhyay (1980), Bhattacharjee (1981), Ara et al. (2000) and Joshi (2008). Weight of the daughter corms of the tested varieties was found highly significant (Table 2). Highest weight of daughter corms (72.90 g) was found in Yellow Summer Sunshine followed by Interpret (57.00 g) whereas it was lowest (46.62) in American Beauty.

Table 1. Effect of corm size and varieties on corm/cormels production of gladiolus grown under Chitwan condition (2008/2009).

\begin{tabular}{l|c|c|c}
\hline Treatments & No. of daughter corms & Weight of daughter corms (g) & No. of cormels/plant \\
\hline corm size $(\mathrm{Fa})$ & & & \\
$2-3 \mathrm{~cm}$ & $1.33^{\mathrm{c}}$ & $43.44^{\mathrm{d}}$ & $41.03^{\mathrm{d}}$ \\
$3-4 \mathrm{~cm}$ & $1.63^{\mathrm{b}}$ & $54.02^{\mathrm{c}}$ & $51.02^{\mathrm{c}}$ \\
$4-5 \mathrm{~cm}$ & $1.75^{\mathrm{ab}}$ & $63.20^{\mathrm{b}}$ & $64.67^{\mathrm{b}}$ \\
$5-6 \mathrm{~cm}$ & $1.87^{\mathrm{a}}$ & $74.70^{\mathrm{a}}$ & $78.74^{\mathrm{a}}$ \\
$\mathrm{SEM} \pm$ & 0.05 & 2.39 & 3.09 \\
$\mathrm{LSD}_{0.05}$ & $0.15^{* *}$ & $7.02^{* *}$ & $9.06^{* *}$ \\
American Beauty & $1.25^{\mathrm{c}}$ & $46.62^{\mathrm{c}}$ & $34.59^{\mathrm{b}}$ \\
Interpret & $1.41^{\mathrm{b}}$ & $57.00^{\mathrm{b}}$ & $101.2^{\mathrm{a}}$ \\
Yellow & $2.27^{\mathrm{a}}$ & $72.90^{\mathrm{a}}$ & $40.82^{\mathrm{b}}$ \\
Sunshine & & & \\
SEM \pm & 0.04 & 2.07 & 2.67 \\
LSD $_{0.05}$ & $0.13^{* *}$ & $6.08^{* *}$ & $7.85^{* *}$ \\
CV\% & 9.56 & 12.21 & 15.75 \\
\hline
\end{tabular}

Figures followed by same letters across the column are not significant $(\mathrm{P}<0.05)$ by DMRT

\section{Numbers of cormels per plant}

Variation in number of cormels per plant was found highly significant due to differences in the size of the mother corms (Table 1). Bigger sized mother corms produced significantly more number of cormels per plant whereas smaller sized mother corm produced less number of cormels. The maximum numbers of cormels (78.74) were produced by 5-6 cm corms followed by 4 -
$5 \mathrm{~cm}$ corms (64.67) whereas lowest numbers of cormels per plant (41.03) were recorded in 2-3 cm sized mother corms. Increased production of cormels/plant was mainly due to the presence of greater amount of stored food materials which promoted vegetative growth and ultimately reflected on corm and cormels production (Mukhopadhyay \& Yadav 1984, Singh 2000, De \& 
Dhiman 2003, Baweza 2003, Dilta et al. 2004) reported that number of cormels per plant was significantly influenced by the size of the mother corms. The effect of varieties on number of cormels per plant was found to be highly significant (Table 1). It varied form 34.59 to 101.2 with a mean value of 58.86. Interpret yielded the maximum number of cormels per plant (102.2) while lowest number of cormels per plant (34.59) were found in American Beauty which was statistically at par with cormels per plant produced by Yellow Summer Sunshine (40.82).

\section{Post harvest behavior}

\section{Total numbers of florets opened per spike}

The effect of corm size on total number of florets opened per spike was found highly significant (Table 2). More numbers of florets/spike were opened in the spikes produced from large sized corms and vice versa. It ranged from 8.00 to 11.40. Spikes from 5-6 cm sized corms opened highest numbers (11.40) of florets/spike followed by spikes from $4-5 \mathrm{~cm}$ sized corms (10.33) while minimum numbers of florets (8.00) were found to be opened in spikes from $2-3 \mathrm{~cm}$ sized corms. The variation in number of florets opened/spike might be attributed to the differential accumulation of carbohydrates due to varied numbers of leaves in plants from different sized corms. This is in conformity with the findings of Barman and Rajni (2004), Nagaraju et al. (2004) and Joshi (2008). Highly significant variations were recorded on total numbers of florets opened per spike among the tested varieties (Table 2). Highest numbers of florets per spikes (11.20) were opened in Interpret followed by American Beauty (10.40), while lowest numbers of florets (7.60) per spike were opened in Yellow Summer Sunshine. The variation in number of florets opened/spike might be attributed to the differential numbers of florets/spike and accumulation of carbohydrates due to varied leaf production. In turn, variation in these aspects might be due to genetic make up of the plants (Shakya 2006).

\section{Days to first floret withering}

The effect of corm size on days to first floret withering was highly significant (Table 2). The largest sized corms were found superior to rest of the sizes in this respect. Spikes of large sized corms i.e. 5-6 cm needed the maximum number of days (6.26 days) to first floret withering followed by spikes from $4-5 \mathrm{~cm}$ corm size (5.80 days), while florets from spikes of $2-3 \mathrm{~cm}$ sized corms needed the minimum number of days (5.00 days) which was statistically at par with days taken by florets of spikes from $3-4 \mathrm{~cm}$ sized corms (5.40 days). The availability of respiratory substrate for longer times due to the higher accumulation of stored carbohydrate during growing period might be the probable reason for late withering of first floret in spikes from large sized corms. Similar result was also reported by Joshi (2008) in gladiolus cv. American Beauty. Highly significant variations were recorded among the tested varieties on days to first floret withering (Table 2). It ranged from 4.45 days to 6.25 days. Interpret needed the maximum number of days to first floret withering (6.25 days) which was statistically at par with days taken ( 6.15 days) by American Beauty, while minimum number of days (4.45 days) was taken by Yellow Summer Sunshine. The differences in days to first floret withering might depends on amount of stored carbohydrate, activity of á-amylase, and spike weight. In turn, variation in these aspects might be due to genetic make up of the varieties.

Table 2. Effect of corm size and varieties on total number of florets opened/spike, days to first and $100 \%$ floret withering of gladiolus grown under Chitwan condition (2008/2009).

\begin{tabular}{|c|c|c|c|}
\hline Treatments & $\begin{array}{l}\text { Total no. of florets } \\
\text { opened/spike }\end{array}$ & $\begin{array}{l}\begin{array}{l}\text { Days to first floret } \\
\text { withering }\end{array} \\
\end{array}$ & Days to $100 \%$ florets withering \\
\hline \multicolumn{4}{|l|}{ Corm size $(\mathrm{Fa})$} \\
\hline $2-3 \mathrm{~cm}$ & $8.00^{\mathrm{d}}$ & $5.00^{c}$ & $11.73^{d}$ \\
\hline $3-4 \mathrm{~cm}$ & $9.20^{c}$ & $5.40^{\mathrm{bc}}$ & $12.40^{\mathrm{C}}$ \\
\hline $4-5 \mathrm{~cm}$ & $10.33^{b}$ & $5.80^{\mathrm{b}}$ & $12.73^{\mathrm{b}}$ \\
\hline $5-6 \mathrm{~cm}$ & $11.40^{\mathrm{a}}$ & $6.26^{\mathrm{a}}$ & $13.13^{\mathrm{a}}$ \\
\hline SEM \pm & 0.25 & 0.15 & 0.11 \\
\hline $\mathrm{LSD}_{0.05}$ & $0.70 * *$ & $0.43^{* *}$ & $0.32 * *$ \\
\hline \multicolumn{4}{|l|}{ Variety (Fb) } \\
\hline American Beauty & $10.40^{\mathrm{b}}$ & $6.15^{\mathrm{a}}$ & $13.45^{\mathrm{a}}$ \\
\hline Interpret & $11.20^{\mathrm{a}}$ & $6.25^{\mathrm{a}}$ & $13.50^{\mathrm{a}}$ \\
\hline Yellow Summer Sunshine & $7.600^{c}$ & $4.45^{\mathrm{b}}$ & $10.55^{b}$ \\
\hline SEM \pm & 0.22 & 0.13 & 0.10 \\
\hline $\mathrm{LSD}_{0.05}$ & $0.61^{* *}$ & $0.38 * *$ & $0.28 * *$ \\
\hline $\mathrm{CV} \%$ & 9.88 & 10.66 & 3.58 \\
\hline
\end{tabular}

Figures followed by same letters across the column are not significant $(\mathrm{P}<0.05)$ by DMRT 


\section{Days to $100 \%$ floret withering}

There was highly significant variation in days to $100 \%$ floret withering (Table 2). Variations ranged from 11.73 days to 13.13 days. Spikes from large corm size needed more number of days while that from small corm needed less number of days for $100 \%$ florets withering. Spikes from 5-6 cm sized corms took maximum number of days (13.13 days) followed by spikes from $4-5 \mathrm{~cm}$ sized corms (12.73 days) while spike from 2-3 cm sized corms took minimum number of days (11.73 days) to $100 \%$ florets withering. Delayed opening of florets with more stored carbohydrate and continuous hydrolysis of starch into sucrose might be the probable reason behind delayed withering of $100 \%$ florets in spikes from large sized corms as compared to withering in small sized corms. The effect of varieties on days to100\% florets withering was highly significant among the tested varieties (Table 2). Interpret took the maximum number of days (13.50 days) which was statistically at par with days taken by American Beauty (13.45 days) to $100 \%$ florets withering, while Yellow Summer Sunshine recorded the minimum number of days (10.55 days). A wide variation in the postharvest life has been reported on gladiolus cut flower due to genetic and varietal factors (Bhattacharjee \& Saxena 1998). These variations have been attributed to variation on cell wall thickening, levels of peroxidase and lignification, as well as the genetic makeup of the cultivars (Gelder 1998).

The size of the corm affects the corm/cormels and post harvest attributes of gladiolus. Large sized corms (5-6 $\mathrm{cm}$ ) performed significantly better as compared to small sized corms in all aspects. Similarly, the performance of gladiolus varieties was also found significantly different in these respects. Among the three varieties, cut flower characteristics were found better in Interpret. Yellow Summer Sunshine performed better with respect to number of daughter corm while numbers of cormels per plant were found highest in Interpret. Likewise, Interpret was found superior having longer vase life as compared to other two varieties with respect to post harvest behavior.

\section{Acknowledgements}

We would like to express our sincere thanks to National Agriculture Research and Development Fund (NARDF) for providing financial support for this research and Directorate of Research and Publication of the Institute of Agriculture and Animal Sciences, Rampur, Chitwan, Nepal for timely providing necessary facilities and logistic supports.

\section{References}

Ara, R., S. A. Chowdhury, F. N. Khan, A. F. M. F. Rahman and K. A. Ara. 2000. Influence of corm size and planting depth on flower and corm production of gladiolus. Bangladesh J. Agril. Res. 25(3):483-489.

Arora, J. S. and K. Khanna. 1985. Evaluation of gladiolus cultivars. J. Research 22(4):655-662.

Bankar, G. J. and A Mukhopadhyay. 1980. Effects of corm size, depth of planting and spacing on the production of flowers and corms in gladiolus. Indian J. Hort. 37(4): 403-408.

Barman, D. and K. Rajni. 2004. Effect of harvest maturity and spike length on postharvest life of gladiolus. $J$. Orna. Hort. New Series 7(2):204-206.

Baweza, H. S. 2003. Sulphur deficiency in relation to the vase life of gladiolus Var. Sel.-1. Scientific Horticulture.8:199-201.

Bhattacharjee, S. K. 1981. Flowering and corm production of gladiolus as influenced by corm size, planting depth and spacing. Singapore-Journal-of-Primary-Industries 9(1):18-22.

Bhattarcharjee, S. K. and N. K. Saxena. 1998. Studies on growth, flowering, postharvest life and quality of rose species. Indian Rose Annual 14:97-103.

Bose, T. K. and L. P.Yadav. 1989. Gladiolus. In: Commercial flowers. (Eds. T. K. Bose and L. P. Yadav). Naya Prakash, Calcutta-7, India.

Deshraj and R. L. Misra. 1998. Potential of gladiolus cultivation in north-western Himalayan region. Ann. Agri. Res. 19(4):423-428.

Devtec Nepal. 1995. Business Plan for cut flower gladiolus. Devtec Pvt. Ltd.

De, L. C., and K. R. Dhiman. 2003. Growth, flowering and corm production of gladiolus as influenced by grades, season and chemicals. Horticultural Journal 15(2):69-74.

Dilta, B. S., S. D. Badiyala, Y. D. Sharma, and V. K. Verma. 2004. Effect of corm size on performance of different gladiolus cultivars. J. Orna. Hort. New Series. 7(2): 53-158.

FAN. 2007. Trade competitiveness of the floriculture subsector in Nepal. Floriculture Association of Nepal (FAN) Teku, Kathmandu, Nepal.

Gauchan, D. P., A. R. Pokhrel, M. Pratap and P. Lama. 2009. Current status of cut flower business in Nepal. Kathmandu University Journal of Science, Engineering and Technology 5(I):87- 98. 
Gelder, A. D. 1998. Compounds of keeping quality used in the variety evaluation. Acta Hort. 261:233-240.

Hedge, M. V. and A. A. Patil. 1995. Studies on genetic variability in gladiolus (Gladiolus hybridus). South Indian Hort. 43:93-95.

Joshi, G. R. 2008. Influence of corm size on cut flower characteristics, corm/cormel production and flower longevity in gladiolus cv. American Beauty. M.Sc. thesis. Tribhuvan University, Institute of Agriculture and Animal Science Rampur, Chitwan, Nepal.

Makhijani, S. 1973. Arranging gladioli. Indian Hort. 18(3):25-28.

Mukhopadhyay, T. P., and L. P. Yadav. 1984. Effect of corm size and spacing on growth, flowering and corm production in gladiolus. Haryana J. Hort. Sci. 13(3/4):95-99.
Pun, U. K. 2004. Commercial cut flower production in Nepal and status of four important cut flowers. J. Inst. Agric. Anim. Sci. 25:17-21.

Shakya, S. 2006. Varietal evaluation and genetic characterization of gladiolus cultivars. M. Sc. Thesis. G. B. Pant University of Agriculture and Technology Pantnagar-263145, (U. S. Nagar), Uttaranchal, India.

Sharma, J. R., and R. B. Gupta. 2003. Effect of corm size and spacing on growth, flowering and corm production in gladiolus. J. Orna. Hort. New Series 6(4):352-356.

Sindhu, S. S. and T. S. Verma. 1995. Promising varieties of gladiolus for commercial floriculture. Haryana J. Hort. Sci. 24(3-4):197-203.

Singh, K. P. 2000. Growth, flowering and corm production in gladiolus as affected by different corm sizes. J. Orna. Hort., New Series 3(1):26-29. 